\title{
An Expo of Their Own: How Ethnic Koreans in Japan Appropriated the Japan World Exposition in Osaka
}

\author{
JEONG HoSeok*
}

Abstract | This paper explores the historical complexity and dynamics of "contributions to the motherland" by ethnic Koreans in Japan associated with Mindan (Korean Residents Union in Japan) and examines the support initiative for the 1970 Japan World Exposition in Osaka (hereafter "Expo"). Mindan established the Korean Residents' Association for the Support of EXPO '70 in August 1969 to engage in various large-scale activities in support of the Expo, including covering the 50,000 US-dollar expense to build and manage the South Korean pavilion, organizing "National Day," and inviting 9,710 compatriots from the homeland. The rapidly growing business community in Osaka, incidentally the leading coalition opposed to Chongnyŏn (General Association of Korean Residents in Japan, affiliated with North Korea), formed the backbone of this support initiative. These businessmen actively developed cooperative and mutually dependent relations with the South Korean government while promoting cooperation and solidarity within the region. Considering the Korean pavilion an opportunity to proclaim the industrialization of South Korea, they projected a multifaceted vision of a "desirable future," emphasizing the organizational power of Mindan to elevate Korean national prestige in the eyes of Japan and the world, as well as in regard to Chongnyŏn. This highlighted the importance of businessmen within Mindan and the Korean community and enhanced the status of Osaka with respect to Tokyo.

Conceived as an identity project under the proposed permanent residency system, the Expo support initiative knitted together local and national patriotism and attested to the possibility of a new kind of "homeland orientation," allowing one to contribute to the homeland, as well as to their local community. The initiative thus served as the setting in which first-generation Korean residents in Japan came to identify themselves as "Zainichi."

Keywords | Ethnic Korean Residents in Japan, Korean Residents' Association for the Support of EXPO '70, homeland contributions, Japan World Exposition, supportive long-distance nationalism, gift as communication

\footnotetext{
* JEONG HoSeok (h_jeong@seigakuin-univ.ac.jp) is a specialist in interdisciplinary information studies and Assistant Professor at Seigakukin University, the General Education Core Curriculum Division.
} 


\title{
Understanding "Homeland Contributions" by Ethnic Koreans in Japan
}

Over the past seventy years, ethnic Koreans in Japan have incorporated themselves into the history of their homeland through various economic contributions and support. ${ }^{1}$ This article examines the dynamics of this involvement and mobilization of ethnic Koreans in Japan with respect to the Republic of Korea (South Korea), focusing on the support initiative for the 1970 Japan World Exposition in Osaka (hereafter "Expo").

In 2016, Mindan (Korean Residents Union in Japan) marked the seventieth year since its founding with a photo exhibition and commemorative celebration touring major South Korean cities under the slogan, "Seventy years running, a new history in the making." The phrase more aptly tying these celebrations together, however, was "contributions to the homeland."

\begin{abstract}
Mindan was there whenever the homeland confronted hardship, working to help the poverty-stricken homeland. Its efforts have encompassed active investment, involvement in New Village [Saemaŭl] projects and the foreign exchange crisis remittance movement, assisting with the 1988 Seoul Olympics, and more. Now the homeland has become a major economic power no longer requiring the support of compatriots residing in Japan. The history of Mindan contributions, however, must not be forgotten.... Let us band together and make sure this is written in the textbooks. (Chae-Ilbon Taehanmin'guk Mindan 2016, 4)
\end{abstract}

As emphasized in this passage, support for the homeland by ethnic Koreans in Japan has been wide reaching and varied. It has included major undertakings, such as the dispatch of a student volunteer force to the Korean War and direct investment. There have also been more locally focused initiatives related to reforestation and inter-regional sisterhood (chiyŏk chamae kyŏryŏn), as well as privately made hometown contributions. Meanwhile, relief activities or remittance movements arose whenever the homeland underwent natural disasters or economic crises (see table 1).

Such activities, commonly referred to as "homeland contributions," or sometimes as "supportive long-distance nationalism" (Anderson 1994; Shipper 2008), provide clues as to the manner in which overseas ethnic groups express ties to the homeland. In particular, they offer an opportunity to examine questions regarding the distinct characteristics of ethnic Koreans in Japan and

1. "Ethnic Koreans in Japan" (chaeil hanin) is a term referring to all ethnic Koreans residing in Japan. Regarding Korean residents in Japan loyal to North Korea (Chongnyŏn'gye chaeil hanin), see Shipper (2010, 60-64). 
Table 1. Homeland Contributions by Ethnic Koreans in Japan ${ }^{2}$

\begin{tabular}{|c|c|c|c|}
\hline Period & Initiative & $\begin{array}{c}\text { Amount } \\
\text { (yen at time) }\end{array}$ & Content \\
\hline \multirow[t]{3}{*}{$\begin{array}{c}1948- \\
59\end{array}$} & $\begin{array}{l}\text { London Olympics Korean team } \\
\text { support }\end{array}$ & 649,500 & $\begin{array}{l}\text { uniforms, sports equipment, } \\
\text { memorabilia }\end{array}$ \\
\hline & Korean War support & $2,030,000$ & $\begin{array}{l}\text { attire, blankets, soap and other daily } \\
\text { necessities }\end{array}$ \\
\hline & $\begin{array}{l}\text { Hometown development } \\
\text { support }\end{array}$ & $9,350,000$ & $\begin{array}{l}\text { gramophones (50), organs (10), sewing } \\
\text { machines, etc. }\end{array}$ \\
\hline \multirow[t]{5}{*}{$\begin{array}{c}1960- \\
69\end{array}$} & $\begin{array}{l}\text { Hometown development } \\
\text { support }\end{array}$ & $30,914,400$ & $\begin{array}{l}\text { sewing machines (46), organs/pianos } \\
\text { (8), streetlights (120), patrol boats, fire } \\
\text { trucks, buses, motorcycles, cars, } \\
\text { cholera vaccine, televisions, recorders, } \\
\text { clothing (thousands of articles), } \\
\text { schools/town halls, saplings (tens of } \\
\text { thousands) }\end{array}$ \\
\hline & Radio Supply Movement & & Japanese radios $(1,337)$ \\
\hline & $\begin{array}{l}\text { Homeland Family Support Fund } \\
\text { Movement }\end{array}$ & $12,856,520$ & \\
\hline & Disaster relief support & $131,174,292$ & $\begin{array}{l}\text { water pumps, rice, flour, clothing, } \\
\text { blankets }\end{array}$ \\
\hline & National defense support & 524,000 & \\
\hline \multirow[t]{3}{*}{$\begin{array}{c}1970- \\
79\end{array}$} & $\begin{array}{l}\text { Hometown development } \\
\text { support }\end{array}$ & $392,644,150$ & $\begin{array}{l}\text { crop-dusting helicopters }(2), \text { patrol } \\
\text { boats, fire trucks, motorcycles }(1,100) \text {, } \\
\text { police motorcycle sidecars }(67), \\
\text { ambulances, x-ray machines, } \\
\text { agricultural machinery, televisions, } \\
\text { video recorders, pianos, wheelchairs, } \\
\text { projectors, photocopiers, Korean beef, } \\
\text { saplings (millions), schools, town halls, } \\
\text { senior citizen centers, rice mills, } \\
\text { stadiums, bridges, road pavement }\end{array}$ \\
\hline & Disaster relief support & $127,843,238$ & relief supplies (tens of thousands) \\
\hline & $\begin{array}{l}\text { Heavy Construction Fund for } \\
\text { Pongsan Shrine, Chinju }\end{array}$ & $\begin{array}{c}600,000,000 \\
\text { (Korean won) }\end{array}$ & \\
\hline
\end{tabular}

2. The total amount of contributions, excluding goods, was about 2.5 billion yen (176.9 billion won), worth about four billion yen (809.6 billion won) in 2012 according to price indexes of the Bank of Korea and the Japanese Ministry of Internal Affairs and Communications. One can assume the actual figure to be much higher, taking into account informal contributions. Furthermore, there were other major contributions related to the nine Korean diplomatic offices in Japan. 
Table 1. (continued)

\begin{tabular}{|c|c|c|c|}
\hline Period & Initiative & $\begin{array}{c}\text { Amount } \\
\text { (yen at time) }\end{array}$ & Content \\
\hline & $\begin{array}{l}\text { Manghyang Park Construction } \\
\text { Fund }\end{array}$ & $500,000,000$ & \\
\hline & National defense support & $11,076,000$ & \\
\hline & $\begin{array}{l}\text { Mindan New Village Sisterhood } \\
\text { Support Fund (148 villages) }\end{array}$ & $\begin{array}{l}516,930,000 \\
\text { (Korean won) }\end{array}$ & \\
\hline & $\begin{array}{l}\text { Mindan Tree-planting Support } \\
\text { Fund (-1981) }\end{array}$ & $36,247,600$ & \\
\hline \multirow[t]{5}{*}{$\begin{array}{c}1980- \\
89\end{array}$} & $\begin{array}{l}\text { Hometown development } \\
\text { support }\end{array}$ & $388,800,000$ & $\begin{array}{l}\text { books (tens of thousands), pianos, } \\
\text { televisions, photocopiers, agricultural } \\
\text { equipment, fire trucks, buses, police } \\
\text { motorcycle sidecars, schools/ } \\
\text { scholarship committees, public offices/ } \\
\text { town halls }\end{array}$ \\
\hline & Disaster relief support & $18,405,000$ & \\
\hline & $\begin{array}{l}\text { Independence Hall Construction } \\
\text { Fund }\end{array}$ & $15,830,000$ & $\begin{array}{l}\text { portrait of independence activist } \mathrm{Yi} \\
\text { Pong-chang (equivalent to } 100,000,000 \\
\text { yen) }\end{array}$ \\
\hline & Peace Dam Construction Fund & $5,400,000$ & \\
\hline & Seoul Olympic Support Fund & $\begin{array}{c}54,096,654,879 \\
\text { (Korean won) }\end{array}$ & \\
\hline \multirow[t]{6}{*}{$\begin{array}{c}1990- \\
99\end{array}$} & $\begin{array}{l}\text { Hometown development } \\
\text { support }\end{array}$ & $94,000,000$ & $\begin{array}{l}\text { scholarship committees, household } \\
\text { electronics, blankets (tens of } \\
\text { thousands) }\end{array}$ \\
\hline & $\begin{array}{l}\text { North Korean Compatriot } \\
\text { Support Fund }\end{array}$ & $17,011,541$ & \\
\hline & Disaster relief support & $205,534,111$ & \\
\hline & Taejŏn Expo Support Fund & $10,000,000$ & \\
\hline & Independence Hall support & & independence activist portraits (60) \\
\hline & $\begin{array}{l}\text { Overseas Students Center } \\
\text { Construction Fund }\end{array}$ & $\begin{array}{l}1,236,000,000 \\
\text { (Korean won) }\end{array}$ & \\
\hline \multirow[t]{3}{*}{$\begin{array}{l}\text { since } \\
2000\end{array}$} & $\begin{array}{l}2002 \text { FIFA World Cup in Korea } \\
\text { and Japan Support Fund }\end{array}$ & $11,500,000$ & \\
\hline & $\begin{array}{l}\text { Donated artistic and cultural } \\
\text { assets }\end{array}$ & $58,000,000$ & $\begin{array}{l}\text { art works }(1,593) \text {, cultural assets } \\
(1,116) \text {, research materials }(68,400)\end{array}$ \\
\hline & $\begin{array}{l}\text { Korean Residents in Japan } \\
\text { Typhoon Relief Fund }\end{array}$ & $\begin{array}{l}359,500,000 \\
\text { (Korean won) }\end{array}$ & \\
\hline
\end{tabular}


Table 1. (continued)

\begin{tabular}{l|l|c|l}
\hline Period & \multicolumn{1}{|c|}{ Initiative } & $\begin{array}{c}\text { Amount } \\
\text { (yen at time) }\end{array}$ & Content \\
\hline \multirow{2}{*}{ since } & $\begin{array}{l}\text { Taegu Subway Fire Disaster } \\
\text { Condolence Fund }\end{array}$ & $\begin{array}{c}107,000,000 \\
\text { (Korean won) }\end{array}$ & \\
\cline { 2 - 4 } & $\begin{array}{l}\text { Sungnyemun Gate Restoration } \\
\text { Fund }\end{array}$ & $\begin{array}{c}587,104,955 \\
\text { (Korean won) }\end{array}$ & \\
\cline { 2 - 4 } & $\begin{array}{l}\text { Korea-Japan Exchange Festival } \\
\text { Fund }\end{array}$ & $79,600,000$ & \\
\hline & $\begin{array}{l}\text { Condolence Fund for Cheonan } \\
\text { Military National Heroes }\end{array}$ & $13,771,233$ & \\
\cline { 2 - 4 } & $\begin{array}{l}\text { Ahn Jung Geun Memorial Hall } \\
\text { Construction Fund }\end{array}$ & $\begin{array}{c}15,000,000 \\
(\text { Korean won })\end{array}$ & \\
\cline { 2 - 4 } & Sewŏl Disaster Collection Fund & $\begin{array}{c}648,231,537 \\
\text { (Korean won) }\end{array}$ & \\
\hline
\end{tabular}

Source: Yi Min-ho (2014, 26-27, 30); Chae-Ilbon Taehanmin'guk Mindan (2016, 46).

Korea-Japan relations in the postwar era.

It is difficult to attribute these "homeland contributions" to a single factor. One could engage in direct investment, for example, due to Korean government influence, self-interest, a sense of patriotism, or a number of other reasons. Accordingly, rather than simply emphasizing "devotion" or criticizing government-driven ideological mobilization, contributions must be explained as a social phenomenon occurring over more than fifty years. This article thus investigates a concrete case-the 1970 Japan World Exposition in Osaka-to reveal the layered and dynamic character of "contributions" to the homeland.

\section{The Japan World Exposition in Osaka and the Korean Residents Association for the Support of EXPO '70}

"Contributions" to the homeland by ethnic Koreans in Japan took on various forms, including involvement in domestic issues, donation of commodities and services, direct investment, technology transfers, and so forth. Support for the homeland also accompanied international events, including the 1964 Tokyo Olympics, 1970 Japan World Exposition in Osaka, 1988 Seoul Olympics, and 2002 FIFA World Cup in Korea and Japan. Events such as the Olympics and World Expo are grand spectacles attracting widespread public attention, as well 
as being media events that bridge the communal aspirations and identities of participants and spectators by mediating their collective imagination (Dayan and Katz 2011). In addition to such qualities, the 1970 Japan World Exposition in Osaka took on particular significance as the first large-scale Mindan enterprise following the 1965 Treaty on Basic Relations between Korea and Japan. Support for this event thus provided an especially meaningful opportunity for ethnic Koreans in Japan to consider their self-identity and relations with the homeland.

The 1970 Japan World Exposition in Osaka, ${ }^{3}$ commonly referred to as the Osaka EXPO or "EXPO 70," was the largest "mega event" hosted by Japan in the postwar era. While partly meant to inform the world of Japan's revival since its defeat in the Pacific War, the Expo also played an important role in the construction of Japanese postwar national identity, as it was attended by citizens from all over the country, just as with the Tokyo Olympics (Yoshimi Shunya 2011). Notably, this Japanese "national event" was also important for the Korean minority in Japan: it was a stage to showcase their presence to the world and a light illuminating the path toward a "new future."

In August 1969 Mindan (then known as the Association of Chosonn Residents in Japan, or Chae-Ilbon Chosŏn Kyŏryumindan) established the "Korean Residents Association for the Support of EXPO '70" (hereafter Support Association). ${ }^{4}$ The purpose of the Support Association was to (1) raise money for the construction of the Korean pavilion, (2) provide support for organizing "National Day" events and managing the overall operations of the Korean Pavilion, and (3) invite family members and relatives from Korea (see table 2).

Considering Mindan's organizational wherewithal at the time, this support initiative would have been quite ambitious. Nonetheless, among its assorted achievements, the Support Association ultimately covered twenty-five percent of the 50,000-dollar (180 million yen, or about 720 million yen today) cost of constructing the South Korean pavilion and facilitated the visits of 9,710

\footnotetext{
3. The Expo opened on March 14, 1970 and ran for about six months. It was the most popular world exposition in history, attended by 64.22 million people, including about half the population of Japan.

4. The Expo Support Association placed the Management Committee and Audit Committee under the jurisdiction of the Presidential Office, of which the Advisory Council was a part. The Executive Office, which was composed of the Department of Planning, Department of Public Relations, and Department of General Affairs, managed practical affairs. With Korean Ambassador to Japan Yi Hu-rak as Supreme Advisor, the Advisory Council was composed of the Head of Mindan Central Headquarters, government representatives, prominent figures in Japanese construction, important representatives from Mindan Central, and wealthy businessmen like Sŏ Kap-ho (Sakamoto Textiles), Sin Kyŏk-ho (Lotte Confectionery), and Han Rok-ch'un (Fuji Tourism) (Zainichi Kankokujin Banpaku and Zainichi Daikanminkoku Kyoryūmindan, 1970).
} 
Table 2. Summary of Korean Residents Association for the Support of EXPO '70 Operations

\begin{tabular}{|c|c|c|}
\hline Pre-EXPO Preparation & EXPO Support & Post-EXPO Wrap-up \\
\hline $\begin{array}{l}\text { - Promotion and education, } \\
\text { distribution of printed } \\
\text { materials and } \\
\text { commemorative } \\
\text { notebooks } \\
\text { - Raising funds for } \\
\text { construction of South } \\
\text { Korean pavilion } \\
\text { - Preparation for invitations } \\
\text { to families in South Korea } \\
\text { - Security measures }\end{array}$ & $\begin{array}{l}\text { - Entertaining key } \\
\text { government figures } \\
\text { including officials from } \\
\text { the Prime Minister's } \\
\text { Cabinet and state guests } \\
\text { - Organizing theater } \\
\text { performances and } \\
\text { "National Day" } \\
\text { - Commemorative } \\
\text { documentary production } \\
\text { - Promotion of Residency } \\
\text { Procurement Movement } \\
\text { and Mindan }\end{array}$ & $\begin{array}{l}\text { - Processing accidents and } \\
\text { other incidents } \\
\text { - Rural Enlightenment } \\
\text { Activities when invitees } \\
\text { returned home (provision } \\
\text { of agricultural equipment, } \\
\text { seeds) } \\
\text { - Confirming invitee } \\
\text { departure } \\
\text { - Settling accounts and } \\
\text { remaining paperwork }\end{array}$ \\
\hline
\end{tabular}

Source: Zainichi Kankokujin Banpaku Kōenkai and Zainichi Daikanminkoku Kyoryūmindan (1970); Author's research.

Koreans to Osaka. ${ }^{5}$ While the Family Invitation Project and related Permanent Residency Procurement Movement will be discussed in further detail below, suffice it to say for now that Mindan aggressively expanded through these efforts to gain a more stable organizational base.

Notably, it is difficult to regard this unprecedentedly large support initiative as the simple fruit of government policy. While the South Korean government called for ethnic Koreans in Japan to contribute 300,000 dollars to the total budget of two million dollars allocated for the project, the Support Association achieved its own fundraising goal of 500,000 dollars. On top of that, it drew up plans for separate enterprises and implored the government to increase the scale of existing projects. Most importantly, ethnic Koreans in Japan led the Expo enterprise to success through active participation. It is thus difficult to explain the subjectivity displayed by ethnic Koreans over the course of this event without reference to the "organized mass movement" that accompanied their proactive planning and voluntary commitment. How might one understand this massive human and material mobilization and active participation? Viewing these as acts of communication, I analyze the involvement and practices of Koreans in this support initiative as a cultural text.

5. The support initiative was judged a "tremendous success." With more than 230 million yen collected for the project and as many as 6.24 million people visiting the Korean pavilion (Osaka Kankokujin Shōkōkai 1985, 424), it was unprecedented in scale. 
Then what might be the significance of understanding "contributions" as communication? First, this approach emphasizes historical process over causality. In other words, rather than the manifestation of specific factors originating at the individual or institutional level, "contributions" are understood as "historical phenomena" gradually developing and transforming through repeated interactions. Although research on ethnic Korean "contributions" has been sparse, there are recent studies examining homeland investment in the Guro Industrial Complex (Chaeil Tongpo Moguk Kongjŏk Chosa Wiwŏnhoe 2008), self-made business ventures (Yi Min-ho 2014, 2015), and Mindanhomeland relations, which are generally divisible into two categories. On the one hand, they focus on the "innate attributes," or "patriotism" (Yi Min-ho 2014), "patriotic ethos," "national pride," and "entrepreneurial spirit" (Ha Myŏng-saeng 2003), ostensibly characterizing businessmen's activities. On the other, they focus on macroscopic conditions such as those pertaining to South Korean political support for Mindan in its competition with Chongnyŏn (General Association of Korean Residents in Japan, affiliated with North Korea) necessitated by the policy needs of the Yusin (Revitalizing Reforms) system (Kim T'ae-gi 2000). Despite the explanatory power of these two approaches, which may be respectively characterized as the voluntaristic approach (emphasizing emotional and ideological orientation) and the structuralist approach (emphasizing Korean government influence), each remains fixated on causality. The task thus remains of examining "contributions" as a social phenomenon in and of itself. No single independent variable, whether behavioral or socio-structural, completely determines a situation in advance of events and interactions. This is because when actor-ascribed subjective meaning translates into specific action amid the operation of multiple variables, an effect emerges transcending intention and leading to structural continuity through repetition. Considering such historical dynamics, "contributions" emerge as a provocative subject of research irreducible to a single causal relationship.

Meanwhile, the concern with "communication" also allows for an exploration of "contributions" on a general level, exceeding rash normative judgments or dichotomous evaluations. Even while contributions may serve as "noble" expressions regarding one's hometown or homeland, they nonetheless also sometimes reflect a rational calculation or strategic purpose. Employing the concept of "communication," contributions are no longer intelligible in mutually exclusive terms, namely, "selflessness" versus "calculation" or "unconditional devotion" versus "deal-making"; instead, they are situated within a historical process characterized by continuity and complexity. The concept of "communication," in other words, captures the complexity of "contributions" 
subsuming simple rational-calculation/irrational-passion or noble/profitseeking dichotomies. This entails analysis not only of dialogic communication based on mutual rapport but also the general practices irreducible to such a pattern: an analysis, in other words, of the effects coloring history precipitated by the non-dialogic communication of contributions. ${ }^{6}$

The remainder of this article thus analyzes the communications of the businessmen, financiers, Mindan organization, South Korean government, and other diverse actors involved in the Expo as a text. It pays particular attention to Mindan facilities and the Expo as the stages of their performative actions. Who were the authors of the text known as the Expo support initiative? What was the nature of the relationships between them? What particular "gazes" did they acknowledge, and what kind of significance did they attribute to the Expo? What was the cognitive-institutional mechanism operating behind the "stage"? What kinds of historical effects and currents did success of the support enterprise engender with respect to its political-social status and the identity of ethnic Koreans in Japan? Taking these questions as a starting point, I present the "contributions" of ethnic Koreans in Japan, variously characterized by the likes of political calculation, economic calculation, and cultural identity, as a single, full-fledged object of research. The article thus looks at the multiple layers and complexity of the Expo Support Association, which was never free from mutually reciprocal relations nor fully incorporated into any transactional relations based on expected benefits or compensation.

6. Beginning with Marshall Mauss, the complex nature of the bestowal of gifts has been extensively explored as a mediator of material interests, social power, cultural recognition and mythical meanings. Borrowing from Georges Bataille's work on the dissemination of destructive consumption or unilateral passion, Derrida (1992) endeavored to renew the understanding of communication in terms of "general economy," which cannot be subsumed under the "restrictive economy" of exchange based on utilitarian calculation. According to him, recipients of gifts assume the need for reciprocity the moment they recognize it. Thus "bestowal" exists only "fleetingly." This aporia of the bestowal calls for a reconsideration of the "dialogic" communication model based on reciprocity, symmetry, and continuity that has existed since Plato (Krämer 2015). From this perspective, considering "donations" as innately at risk of retroactive "contamination" at the structural level, the problematic "selfless donation" cannot but transform into the quest for historical progress regarding the assumption of reciprocation, while essentialist and causal questions regarding the purity or "true motive" of donations cannot but transform into one's concerning triggered effects and mediation. 


\section{Expo Support as Reciprocal Communication}

\section{The Rise of Osaka Business Networks and the Formation of Cooperative Relations with the South Korean Government}

This section begins by elucidating Expo support activities at the external and macro levels, focusing on the actors who carried them out. In the 1970s, "Korean residents in Japan" began to take on unprecedented economic and political significance. Responding to the attention and expectations of the South Korean government, Osaka-region businessmen became the driving force of the Expo support campaign as they endeavored to establish reciprocal relations with the homeland.

The most remarkable aspect of the Korean pavilion construction fundraising initiative, a central project of the support initiative, was the active role played by Mindan-associated businessmen from the Osaka region. Although the Support Association was officially an ad-hoc organ of Mindan Central Headquarters, since the Expo was being held in Osaka where a number of businessmen were concentrated, the Support Association was launched under the jurisdiction of leaders in the Osaka area. Osaka Kōgin (hereafter "Kōgin") Chairman Lee Heui Keon was appointed Support Association President, with Osaka Shōgin (hereafter "Shōgin") Chairman Pak Han-sik serving as Honorary President and Shōgin Vice Chairman Kang T'aek-u as Executive Vice President in charge of managing funds. While the Support Association Board was composed of about eighty members, there were six Osaka representatives on the nine-member standing committee. Above all, key members from the two largest credit unions in Osaka, Kögin and Shōgin, directed Support Association affairs, and the opening ceremony was held at the Korean Chamber of Commerce and Industry in Osaka (KCCIO) (see figure 1). The dominance of businessmen in the support initiative was further exemplified by the results of the fund collection movement. Seventy percent (128.1 million yen) of the total 180 million yen raised came from the Osaka region, and fifty out of the fifty-nine large donors (more than one million yen) were KCCIO members.

The formation of mutual assistance networks among ethnic Korean businessmen began in the 1950s as Japan entered a period of high economic growth. In the case of Osaka, increasingly influential entrepreneurs formed vibrant local networks in the early 1950s as they moved from the prewar textile and rubber manufacturing industries to the postwar sale of military supplies and daily necessities on the black market. The Korean Residents in Japan Chamber of Commerce (Chae-Il Han'gugin Sanggonghoe), founded in 1953 


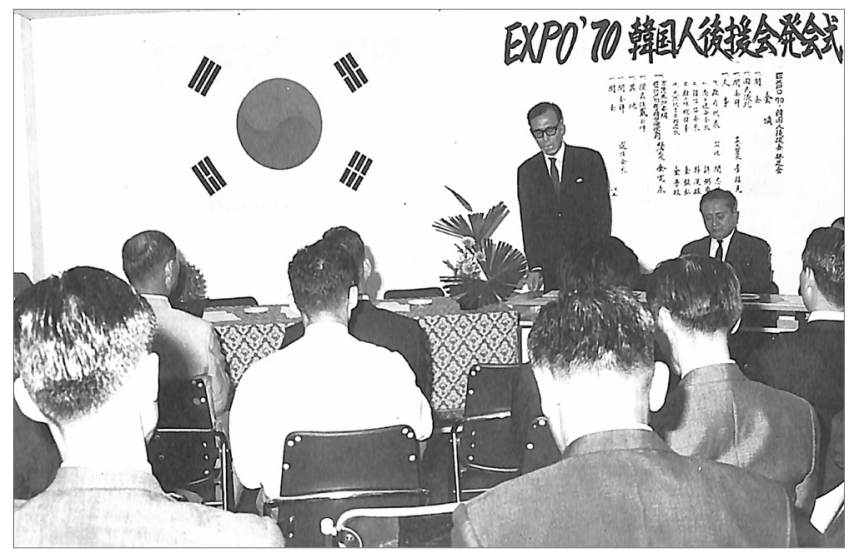

Source: Osaka Kankokujin Shōkōkai $(1988,214)$

Figure 1. Korean Residents Association for the Support of EXPO '70 Opening Ceremony

under the auspices of Mindan, absorbed the Korean Business Association in Japan (Chae-Il Kansai Han'gugin Sirŏphoe), established a common trading company for dealing with the homeland, and formalized relations with the homeland by integrating local businessmen via dispatches to the homeland on commercial business. At the time, Mindan-affiliated credit associations provided the impetus for such change. Shōgin was a credit union jointly established by ethnic Koreans and Japanese in the Umeda region in 1953 to handle loans, taxes, and other business matters and offset ethnic discrimination. Within ten years it had amassed more than three billion yen. Meanwhile, Kōgin, a latecomer established in 1955 and focusing on the international market in Tsuruhashi, amassed 2.9 billion yen in deposits by early 1964 through aggressive sales expansion based on a thorough "customer-first" policy (Yang Kyŏng-hŭi 2009, 16-18; Chaeil Tongpo Moguk Kongjŏk Chosa Wiwŏnhoe 2008, 94-96). In May 1956, the five Mindan-associated credit associations, including Shögin and Kögin, formed the Korean Credit Association in Japan (Chae-Il Han'gugin Sinyong Chohap Hyŏphoe). The Korean Economic Association in Japan (Chae-Il Han'gugin Kyŏngje Yŏnhaphoe) was then established in 1959, and The Federation of Korean Industries in Japan (Chae-Il Han'gugin Sanggongin Yŏnhaphoe), amalgamating Mindan-affiliated economic organizations all across Japan, was established in 1962. Mindan-associated businessmen accordingly set out to establish intimate relations with the homeland explicitly in relation to the competition with Chongnyŏn-affiliated credit unions. As small and medium-size 
business owners began to distinguish themselves under the favorable "Izanagi" economic boom in the late 1960s, a tide of systematic direct investment decisively overtook informal sporadic investment in the homeland. The Expo support initiative in 1970 represented both a reflection and acceleration of these conditions.

Meanwhile, Mindan abandoned its historical opposition to the home government's "disregard policy" and its "resolution of disapproval of the Liberal Party" (1959) and committed its support to the Park Chung-hee administration, inaugurated in 1961. However, Mindan continued to experience internal conflict due to opposition from associations under its jurisdiction, such as the Korea Youth Alliance in Japan (Chae-Il Han'guk Ch'ongnyoun Tongmaeng) and the Korean Student Alliance in Japan (Chae-Il Han'guk Haksaeng Tongmaeng), as well as suspicion of "pro-Japan" elements within the executive branch. Thus, in reality, Mindan also distrusted, held in check, and agitated against the South Korean government until the mid-1960s. During this time, the "National Financial Institution Establishment Movement" functioned as an important catalyst in the formation of amicable relations between Mindan and the South Korean government. Until the mid-1960s Mindan had been weaker in both organizational and financial terms compared to its Chongnyŏn counterpart. In particular, businesses unable to procure loans from Japanese financial institutions were increasingly looking to the Chongnyŏn-affiliated Tonghwa Credit Union (Tonghwa Sinyong Kŭmgo) for funding. In order to stem the tide of "member loss" in the 1960s, Mindan accordingly set out to support the nationwide expansion of co-operative and commercial banks. The active involvement of the Park Chung-hee administration in this process led to fullfledged cooperative dependence between business people, Mindan, and the Korean government.

The position of the Park administration in the mid-1960s with respect to "ethnic Koreans in Japan" was twofold. First, it aimed to foster and strengthen Mindan and enable it to effectively resist against Chongnyorn, which opposed the Treaty on Basic Relations between Korea and Japan. Second, it anticipated private investment by ethnic Koreans in Japan that might serve as an informal source of capital to complement the "economic cooperation funds" provided by Japan through the Treaty on Basic Relations as revenue for the revised economic plan (Kim T’ae-gi 2000, 79; Yi Hyŏn-jin 2010, 302). The importance of Mindanaffiliated businessmen was thus clearly apparent in these two considerations, premised on the residence of Koreans in Japan. Against this background, in early 1961, the Park administration implemented a 500,000 US-dollar government loan (National Small Business Promotion Fund Tongpo Chungsogiŏp Yuksŏng 
Kigŭm) neglected since 1953. At the time, Korean Credit Association in Japan Vice Chairman and Kögin Chairman Lee Heui Keon played an important role in the regional distribution of these funds. Altogether, almost half of the funds were allocated to Osaka through Kögin and Shögin. Through this process, following his success in founding Kōgin, which amalgamated fourteen large credit unions across Japan and amassed 15.7 billion yen in just fourteen years, Lee Heui Keon became a prominent figure within the Korean resident community. The role of Lee's extensive network was also considerable with respect to the unprecedented "goal surpassing" of fund collection for the Expo support initiative.

The Expo Support Association was an enterprise on which Osaka businessmen staked their very existence. Kögin and Shögin, the two major credit associations undergoing rapid and expansive growth at the time, functioned as the indispensible driving force behind the enterprise's success. By March 1970, the Mindan-affiliated Korean Credit Union in Japan had amassed deposits totaling 20.1 billion yen, surpassing levels of the Chongnyŏn-affilliated Tonghwa Credit Depository. The fact that Chongnyon, overwhelmingly dominant in the past, was overtaken due to economic rather than ideological reasons was widely regarded as "symbolic of the times." The Expo support initiative thus emerged as the fruit of the relationships established between Osaka businessmen, Mindan, and the South Korean government in the late 1960s.

\section{The Reciprocal Communication of "Loyalty" and "Recognition": Expo Support and National Honors}

In considering the determination of these businessmen, patron-client communication bestowing the recognition of "devotion" to organization and community is one factor that cannot be overlooked.

As emphasized within the literature on social capital, high levels of cooperation and communal solidarity emerge through processes of repeated mutual interaction believed to have potential benefits, even where the prospects of immediate gain are lacking. This conceptualization of social capital encompasses not only institutional and structural factors such as laws, procedures, rules, punishment, and sanctions meant to elicit, stimulate, and manage certain kinds of behavior, but also intangible, cognitive elements such as values, beliefs, and attitudes (Uphoff 2000, 218-21). Among Mindan personnel from Tokyo, consisting mostly of elites educated abroad and self-made businessmen, solidarity and conflict has traditionally tended to form along ideological lines. Conversely, united by a common Cheju Island origin and the cooperation 
necessitated by black-market trading since the 1950s, ethnic Koreans residing in the Osaka region developed comparatively more intimate and interdependent local relations. Business organizations, such as the two major credit associations, were the major mediator of that accumulated social capital.

South Korean governmental "recognition" emerged in the late 1960s to complement such local conditions influencing individual conduct. To be sure, the Expo Support Association outwardly legitimized its actions in terms of patriotism and nationalism.

The home government ... has allotted a portion of 500,000 US dollars to be raised by Korean residents in Japan through contributions to large-scale businesses. We have responded positively to the homeland, which has bestowed the honor of actively planning the sacred World Expo enterprise ... Regarding the Expo Support Association Fund Collection Enterprise undertaken by Korean residents in Japan, which the South Korean Government is watching with great interest and anticipation, we are already preparing to surpass the allocated funding targets in each region. Through solidarity and tireless effort, we are working to ensure the success of the sacred fund collection movement. (Zainichi Kankokujin Banpaku Kōenkai and Zainichi Daikanminkoku Kyoryūmindan 1970, 21-22; emphasis added)

As conveyed in the passage, the Expo Support Association was grateful to the government for allowing Korean residents in Japan to participate in this "sacred" national cause, even if this participation consisted of donating money earned through "blood, sweat, and tears" in the midst of poverty. What is most noteworthy in this rhetoric is the clear recognition of the South Korean government's "gaze."

The most important forms of institutional social capital were government medals and commendations, which functioned as a part of a psychological compensation system. From the late 1960s to early 1970s, as government honors were being actively utilized as a strengthening measure for government legitimacy, a marked shift occurred as Korean residents in Japan became the regular recipients of honorary medals (hunp'ojang), including the Grand Order of Mugunghwa (Rose of Sharon) Medal (see table 3).

The primary recipients of these honors were Mindan-affiliated organizations and businessmen. The Korean government began to officially "recognize" national financial institutions in Japan in the mid-1960s. An event that is symbolically representative of this was the South Korean Prime Minister's congratulatory address given in October 1965 at the Kögin board meeting held in Seoul (Sŏul Ch'ulchang Isahoe). In 1969, fifteen years after Kōgin's founding, Chairman Pak Han-sik and the locally influential Han Rok-ch'un each received 
Table 3. Government Honors Awarded to Korean Residents in Japan (1963-80)

\begin{tabular}{l|c|c|c|c|c|c|c|c|c|c|c|c|c|c}
\hline Year & '68 & '69 & '70 & '71 & '72 & '73 & '74 & '75 & '76 & '77 & '78 & '79 & '80 & $\begin{array}{c}1963-80 \\
\text { (total) }\end{array}$ \\
\hline $\begin{array}{l}\text { Honor } \\
\text { Mugunghwa Medal }\end{array}$ & 0 & 0 & 1 & 2 & 0 & 1 & 2 & 0 & 1 & 0 & 2 & 2 & 0 & 11 \\
\hline $\begin{array}{l}\text { Order of Civil Merit, } \\
\text { Moran Medal }\end{array}$ & 1 & 0 & 0 & 2 & 1 & 3 & 1 & 2 & 0 & 11 & 8 & 8 & 0 & 37 \\
\hline $\begin{array}{l}\text { Order of Civil Merit, } \\
\text { Tongbaek Medal }\end{array}$ & 13 & 0 & 1 & 21 & 0 & 1 & 6 & 36 & 71 & 0 & 48 & 33 & 0 & 230 \\
\hline $\begin{array}{l}\text { Order of Civil Merit, } \\
\text { Mongnyŏn } \\
\text { Medal }\end{array}$ & 0 & 0 & 0 & 0 & 0 & 0 & 0 & 13 & 0 & 0 & 9 & 13 & 2 & 37 \\
\hline $\begin{array}{l}\text { Order of Civil Merit, } \\
\text { Sŏngnyu Medal }\end{array}$ & 0 & 0 & 0 & 1 & 0 & 0 & 0 & 0 & 0 & 1 & 0 & 0 & 0 & 3 \\
\hline $\begin{array}{l}\text { Motal (inclu- } \\
\text { Medal of Honor }\end{array}$ & 3 & 0 & 0 & 13 & 4 & 0 & 0 & 0 & 0 & 0 & 0 & 0 & 1 & 21 \\
\hline $\begin{array}{l}\text { Soung one } \\
\text { in 1963) }\end{array}$
\end{tabular}

Source: compiled from data in Mindan Tokyo 50-nenshi Hensan Iinkai (1998, 514-22) and Chaeil Tongp’o Moguk Kongjŏk Chosa Wiwŏnhoe (2008, 256-94).

the Order of Civil Merit Tongbaek (Camellia) Medal, and Park Chung-hee bestowed upon Kōgin the handwritten honor of "Common Faith and Prosperity" (kongsin kongyŏng). In 1970, the government granted honors on an unprecedented scale, presenting the ninety-seven contributors to the Korean Expo Pavilion Fund with the Prime Minister's Commendation (Kungmu Chongni P'yochiang) or the Ministry of Commerce and Industry Commendation (Sanggongbu Changgwan P'yochiang). The recipients travelled to Seoul to attend an award ceremony and congratulatory celebration at the Capitol Building before returning to Japan and complementing these honors with a Mindan ceremony. With respect to the Permanent Residency Movement, as well, the government granted 112 people with medals or certificates. In the same year, Koggin received a Presidential Commendation and Chairman Lee Heui Keon became the first Korean resident in Japan to receive the Mugunghwa Medal. Meanwhile, Shoggin Vice Chairman Kang T'aek-u received a Prime Minister's Commendation, Han Rok-ch'un the Mugunghwa Medal, Shōgin a Presidential Commendation, Osaka Korean Business Association President Yu Su-hyŏn the Tongbaek Medal, Shōgin Chairman Pak Han-sik the Mugunghwa Medal, and Tokyo Shōgin Credit Union Chairman Heo P'il-sik the Mugunghwa Medal. Following that, in 1974 the Tokyo Shōgin Credit Union received the Presidential Commendation upon the 
twentieth anniversary of its founding and twenty-four Ministry of Foreign Affairs Commendations were given in appreciation of the construction of the Mindan Central Building (Mindan Chungang Hoegwan). Thus, as Mindan actually came to play an "important role in the Yusin system" in the late 1970s, the reception of medals and commendations by Mindan-affiliated businessmen became more and more common, as attested to in the increasingly ubiquitous images of President Park Chung-hee handing out medals to Mindan executives and businessmen and the cocktail parties that followed.

It is not difficult to deduce the decisive effect such commendations legitimizing Mindan enterprises as "patriotic contributions" had on the conduct of ethnic Koreans in Japan. In terms of maintaining national consciousness amid discrimination and a lack of legal status since liberation, government medals served as a powerful weapon, particularly in the manner in which they created a sense of "sympathy" with the supreme power in the homeland, President Park Chung-hee.

In several interviews I conducted, especially among the men, medals were repeatedly emphasized as an important motivator for participation. As a further example, the biographies of prominent ethnic Koreans in Japan who participated in the support initiative are, without exception, brimming with



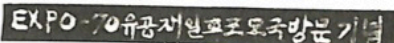

Source: Osaka Kankokujin Shōkōkai $(1983,424)$.

Figure 2. Commemorative Photograph of the Homeland Visit by Contributors to the Osaka Korean Residents Association for the Support of EXPO '70 
large photographs of medal-adorned participants (see figure 3). Allusions to distinguished service are also prevalent in memoirs of support initiative participants, as well as in various other publications commemorating meetings and events.

The Expo fund collection movement was, in and of itself, a kind of "donation" devoid of considerations about any immediate economic compensation. But in terms of the manner in which this movement promoted social credit and solidarity among businessmen and donors' reputations, it was also clearly an accumulation of social capital. Furthermore, even if not necessarily recognized at the time, such philanthropic activity came to constitute a form of reciprocal communication, as it was retroactively incorporated into the compensatory system of medals and commendations. Regardless of their initial motivation, in other words, such action showed the possibility of achieving public recognition through "honorific titles, medals of honor, awards of distinction, certifications of service, and ceremonies," all of which are "mass-circulated assets" (Lin 2001, 152). It thus engendered expectations with regard to the potential benefits of one's conduct, both tangible and intangible. In this manner, if certain actions lead to repeated positive-sum gains, they become self-reinforcing, generating a specific social structure based on virtuous cycles of action (Bourdieu 1986;
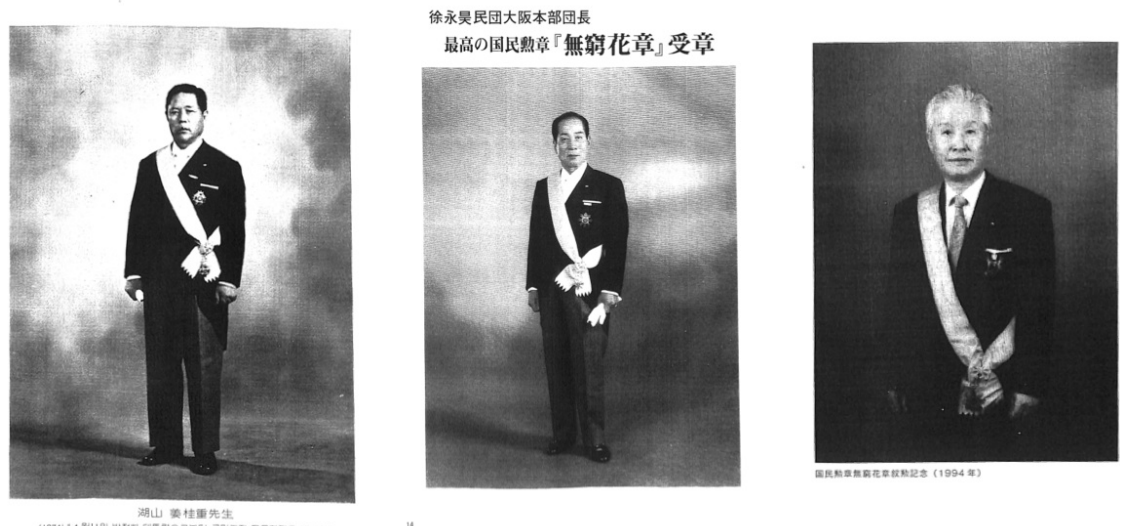

Source (from left to right): Kang Kye-jung (Mindan Osaka Central Headquarters director, standing advisor) (Hosan Kang Kye-jung Kanhaeng Palgi Wiwŏnhoe 1979); Sŏ Yŏng-ho’s (Mindan Osaka Central Headquarters director) Autobiography; Pak Pyŏng-hŏn’s (Expo Support Association secretary general, Mindan Osaka Central Headquarters director) Autobiography (Pak Pyŏng-hŏn 2011, 3).

Figure 3. Photographs from Autobiographies of Ethnic Korean Medal Recipients in Japan (1963-80) 
Putnam 1993; Adler and Kwon 2000). Since the 1970s, the act of justifying and proclaiming Mindan enterprises as "patriotic" has become an established ritual, for which the Expo support initiative functioned as an important impetus.

\section{"Homeland Future" and "Zainichi Future"}

\section{The Korean Expo Pavilion Construction Initiative and Imagining the "Future"}

What kind of meaning might the Expo Support Association have conferred upon the Exposition? Mindan newspapers and various other materials ${ }^{7}$ imbued the approaching "mega event" with the association's own particular meaning and translated this shared understanding into substantive power. In this section, reflecting on the manner in which the meaning of the Expo was appropriated in terms of reference, understanding, and reinterpretation, I seek to show the character of the Expo support initiative in terms of how it facilitated the search for a new self-image among first-generation ethnic Koreans in Japan.

One particular characteristic that stands out in the Expo support initiative discourse is the "imagining of the future." Shunning any mention of the war and colonization, such discourse emphasized looking toward the "future" rather than becoming bogged down in the "past." This "past/future" rhetorical juxtaposition was consistent with other commonly used binary oppositions, such as Chongnyŏn/Mindan, politics/economy, 1960s/1970s, and conflict/peace. Unlike Chongnyŏn, which relied on allusion to the past in its opposition to the Treaty on Basic Relations between Japan and Korea and the mission to "return home," Mindan repeatedly emphasized creating a new future, and facilitating amicable relations between Korea and Japan. This meant replacing the ideological, divisive "political" rhetoric of the 1960s, exemplified by the Treaty on Basic Relations, with that of "economic" development in the 1970s to establish a new basis of prosperity. This imagined "future" took form on the pages of Mindan-affiliated newspapers, which reported on preparations for the Expo in articles and photos related to the construction of the Korean pavilion and visits by families from Korea.

This kind of "future-oriented" character was palpable in the issues of

7. Association publications: Mindan shinbun (Mindan News), Kankoku shinbun (Korea News), Shinsekai shinbun (New World News), KPI tsūshin (KPI Communication), Korian supōtsu taimuzu (Korean Sports Times), and Pangnamhoe kinyŏm suchǒp (Expo Commemorative Notebook). Other publications include Mindan Central Headquarters and branch materials and memoirs. 
Mindan-affiliated newspapers in early 1970. Rather than a simple "New Year's greeting," articles tended to describe the aspirations of a "new age" and the "mission" of ethnic Koreans in Japan. For example, there was Prime Minister Satō Eisaku's "For the Prosperity of the Far East" and the Minister of Foreign Affairs' "Korea-Japan Relations in Development." In addition, Expo Support Association Chairman Lee Heui Keon asserted in his column "Enhancing National Prestige through the Expo," "For the Republic of Korea, the 1970s will be an age of advancement into 'modernization' on the basis of economic prosperity," and that Korean residents in Japan "need to keep pace with this rapid development of the homeland" (Kankoku shinbun, January 1, 1970, 3). What was particularly notable was how this discourse reinterpreted the official Expo theme. Represented by the slogan "Peace and Harmony for Humanity", the Expo theme emphasized "civilizational" concerns, such as harmony between human beings, technology and nature, and overcoming regional and ideological strife. The theme of the Korean pavilion, on the other hand, signified by the slogan "Deep Understanding and Friendship," was restricted to the "bright future" of cooperative relations between Korea and Japan, inaugurated by the Treaty on Basic Relations, and forewent any mention of the colonial past. Furthermore, "harmony and peace" and "understanding and friendship" were not simply appropriated with regard to Korea-Japan relations but also to build cooperative relations between Mindan ("politics") and businessmen ("economy"). Urging the acceptance of the Expo themes as the "spirit of Expo support," Lee Heui Keon wrote, "Understanding and cooperation between the organization and businessmen will enhance the Republic of Korea's national prestige and ensure the success of the Expo support initiative." As attested to by the active role Osaka businessmen played in the fund collection movement, the Expo provided an auspicious opportunity to improve the status of Korean businessmen in Japan, who had been marginalized by their political counterparts thus far, and their hometown of Osaka. It appears then that the Expo support initiative acquired a more substantive impetus, as it came to be associated with the "desirable future" articulated by these businessmen concerned with rebalancing existing power relations.

Meanwhile, Mindan agencies raised expectations regarding the homeland through various promotional activities, including the first Korean product exhibition (Korean Fair) held at a department store, clothing showcases, cooking classes, and photo exhibitions displaying photos of downtown Seoul and symbolizing the "modernizing homeland of today." These agencies also endeavored to maintain a festive atmosphere throughout the support initiative by presenting round-trip airline tickets to "Expo Baby" parents (who gave birth 
during their visit), as well as prizes for the "Lucky Visitor" who became the sixmillionth at the Korean pavilion. This sort of promotion culminated in the holding of "National Day" festivities on May 18, for which the Korean pavilion was the focal point.

The Korean pavilion was clearly meant to announce Korea's entry into the club of industrialized nations. Newspaper articles about it were accompanied by large photographs, filling a third to half of the page, displaying the turquoise cylindrical structures meant to look like chimneys from Korea's "booming industry" (see figure 4). Such articles consistently reflected the pride in and success of the support initiative, exemplified by the construction of the pavilion and holding of "National Day" events (see figure 5). They also emphasized the nationalistic demand that ethnic Koreans in Japan play an active role in the future of the homeland, which was overcoming poverty and undertaking industrialization.

To Western nations, the Expo was like an "industrial Olympics"; it was a "presentation" staging the approaching future by displaying cutting-edge technology and levels of industrialization. To developing and post-colonial nations, however, this was exotic scenery pandering to the orientalist desires of the masses. In the case of the Korean pavilion at the World Expo in Osaka, the design clearly emphasized "industrialization" over traditional culture, a characteristic notably incongruent with the overall Expo theme of seeking "harmony." Nonetheless, it would be erroneous to conclude that the pavilion

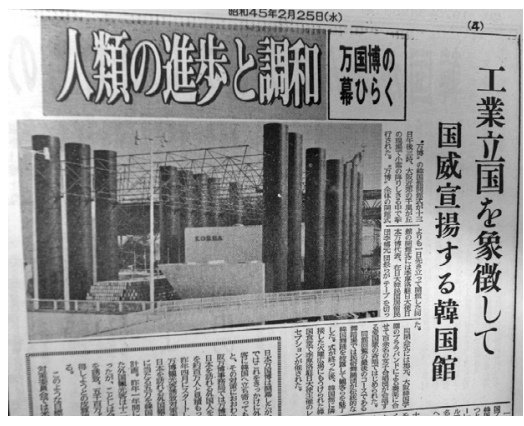

Source: Kankoku shinbun (February 25, 1970, 4).

Figure 4. Korean Expo Pavilion in a Mindan-affiliated newspaper ("Korean Pavilion Raising National Prestige Symbolizing Emergence as Industrial Nation")



Source: Kankoku shinbun (May 23, 1970, 1).

Figure 5. Japan World Expo "National Day" as portrayed in Mindan-affiliated newspaper ("National Day: Expo Chairman Surrounded by Koreans") 
bore a univocal meaning for a unitary audience. This is because it communicated "messages" at the performative level different from those communicated at the semantically distinguishable constative level of the intended design. As the ninth largest pavilion among seventy-seven, the Korean pavilion displayed a "vision of 1970s industrialization," which allowed ethnic Koreans in Japan to overcome the inferior and negative stigma pertaining to themselves and the homeland. This was both the communicating medium of the politics of representation meant to improve the image of ethnic Koreans in Japan within Japanese society, as well as a means of demonstrating to the South Korean government their economic capacity and "loyalty." Furthermore, to central figures and elites within Mindan, the pavilion served as a platform for communicating the rise of Osaka, particularly Osaka-region ethnic Korean businessmen. It was also a channel for dramatic reunions of separated family members and a symbol of their success in a foreign land. Through the Expo support initiative, the "past" that these actors longed to overcome and sublateone characterized by subjection to colonial rule, conflictive Korea-Japan relations, the political division of Mindan, Kanto/Tokyo Mindan superiority, and an impoverished homeland-actually consisted of complex "pasts" irreducible to a single origin. As a stage for performing and exhibiting the very struggle with these multiple pasts rather than a single vision of Koreas future, the Korean pavilion allowed diverse visitors, including South Korean government representatives, South Korean citizens, Japanese citizens, and ethnic Koreans residing in Japan, to understand and anticipate the "future of Koreans."

Naturally, advocacy for this vision of the "future of a strong industrialized nation" may also be attributed to an uncritical reception of recent Yusin-regime propaganda. Considering the subjective participation of ethnic Koreans in Japan, however, the Korean pavilion could hardly be a simple reflection of government intentions. To ethnic Koreans in Japan, the "Expo" was a multi-level project representing the strengthened right to speak about the homeland, the display of Mindan's power to Chongnyŏn-affiliated Koreans in Japan, and the enhancement of the status of Osaka businessmen. Although most ethnic Koreans in Japan were completely excluded from the decision-making process pertaining to the Korean pavilion, for them the "Expo" was something transcending the national business of South Korea. This was an independent and subjective event into which these people identifying as "Zainichi" poured incredible amounts of support and effort. One must thus transcend mere intention and expectation to understand it and evaluate historical effect rather than the "reciprocity" characterizing intra-regional networks and reception of government honors. 


\section{The Happy Combination of Local and National Patriotism: The Family Invitation and Permanent Residency Movements}

One such effect of the Expo support initiative was the discovery of family invitations as a new repertoire for contributing to the homeland in the "age of permanent residency," as well as enlarging Mindan membership. As evident in phrases such as "Expo together with relatives and old friends" and "Expo Support, Invitation Initiative" scattered across countless newspaper front pages, family invitations, along with fund collection, constituted a core component of the support initiative. This issue was particularly pressing due to its relevance to permanent residency, a condition stipulated in the Treaty on Basic Relations between Korea and Japan. Thus, albeit an ostensibly "pure" and apolitical matter, family reunions unexpectedly became the object of an extremely political campaign. Meanwhile, they served as the backdrop for rapid increases in Mindan affiliation among ethnic Koreans in Japan.

This expo is a grand opportunity to effectively introduce our culture to the world. For this, the home government has also committed to contributing to the enormous budget and constructing the Korean pavilion that shall enhance the prestige of the nation. While improving national prestige is extremely important for improving the morale of ethnic Koreans residing in Japan, it is particularly important to allow our Chongnyŏn-affiliated compatriots, who may come to see the Republic of Korea in a new light by observing the superiority of our position, an opportunity to convert to Mindan. For this purpose, Mindan ... has committed to undertaking the "Expo Participant Invitation Initiative." By inviting families and friends from the homeland to participate in the Expo, besides offering an opportunity for contact with the commercialized civilization of advanced nations, this initiative shall widen their perspective and allow them to contribute to the industrial development of the homeland upon their return. Meanwhile, it shall allow families and friends residing in Japan a deeper understanding of the homeland by conveying the status of its modernization enterprise. Finally, it shall augment their national consciousness and repel the Chongnyŏn false propaganda offensive. (Kankoku shinbun, July 5, 1969, 3)

Not only was the Expo Family Invitation Initiative legitimized in terms of family reunions and local patriotism, but also through strengthening Mindan, providing enlightenment about the industrial development of the homeland, and augmenting the national consciousness of ethnic Koreans in Japan. As a "long-cherished wish" (Pak Pyŏng-hyŏn 2011, 132), Mindan had actually first carried out the invitation of hometown families during the 1964 Tokyo Olympics, inviting 2,957 people. The initiative encountered various difficulties at the time, however, due to complicated procedures and prohibitive costs. By comparison, 
the Expo support initiative complemented the knowhow of this first effort with ample funding and solid planning, and this time family invitations did not simply amount to one-off reunions; it was rooted in the grand and futureoriented goal of "solidarity" regarding residency in Japan.

For Mindan and the South Korean government, above all else, the family invitation initiative was a timely means for resolving the issue of inadequate residency registration. Permanent residency registration had begun on January 17, 1966 and was to be concluded by April 18, 1971. By early 1968, however, just ten percent (about fifty thousand) of the ethnic Korean population had been successfully registered (Kim T'ae-gi 2000, 83-84). The South Korean government accordingly instructed the Korean embassy in Japan and Mindan to direct all of their energies into resolving the permanent residency issue. In addition, it invited more than eighty Mindan executives to Seoul to participate in the "Mindan Strengthening Policy Conference" (August 7-8) and issued a joint communiqué together with the Japanese attorney general outlining measures for the simplification of residency procurement (August 20). Against this backdrop, Mindan formed the Residency Procurement Promotion Committee in September, initiating the "enlightenment movement" in earnest. Originally there had been no need to associate the residency issue with Korean participation in the Expo. As time passed, however, the family invitations and residency registration initiatives came to be promoted as "inseparable." In particular, family invitations were mainly utilized as propaganda for winning over neutral and Chongnyŏn-affiliated compatriots.

In 1970, designating "residency registration promotion" and "Expo support/ family invitation" the "two most important initiatives," Mindan began a promotion campaign consisting of national television, radio, and newspaper advertisements, artistic performances, film screenings, rallies, posters, and pamphlets (Kim Pu-hwan 1977, 305) with the objective of increasing the resident registration rate to twenty thousand per month. With "honor on the line," local branches took emergency measures to accomplish this goal, dispatching writing, logistics, propaganda, and information task forces to the administrative office to assist in the registration process (figure 6) and "touring speech corps" that would circulate local districts in special propaganda cars (figure 7) proselytizing door-to-door.

Meanwhile, Mindan Osaka Central Headquarters came to play the role of "national coach" in the Residency Procurement Movement, with business leaders once again displaying particular initiative. Mindan Osaka Central Headquarters was the first in the nation to hold the Convention Commemorating the Establishment of the Residency Procurement Promotion Committee 
Source: Chae-Ilbon Taehanmin'guk Mindan $(2016,31)$.

Figure 6. Mindan administrators assisting in residency registration

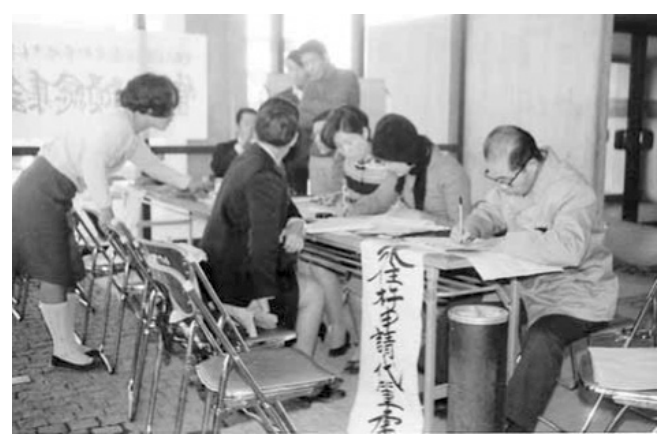

Source: Zai-Nihon Daikanminkoku Mindan Aichi-ken Chihō Honbu $(2007,145)$.

Figure 7. Mindan Residency Procurement Movement propaganda car

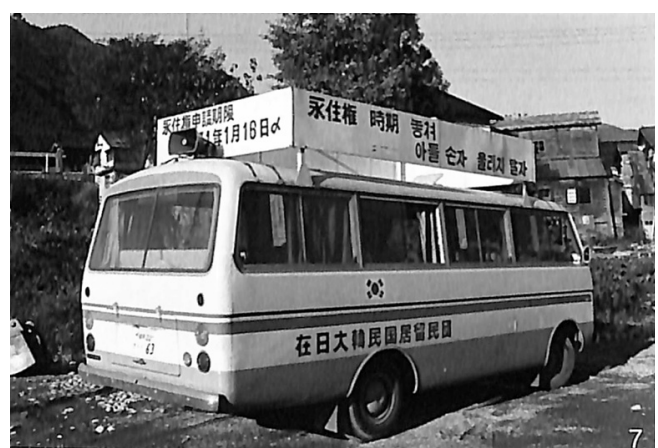

(September 1), attended by more than eight hundred community leaders, including Sŏ Kap-ho (Sakamoto Textiles), Lee Heui Keon (Kōgin, Expo Support Association), Kang T’aek-u (Shōgin), and Pak Han-sik (Korean Credit Association in Japan) (Kim Pu-hwan 1977, 309). The KCCIO also organized its own assembly and briefing session, and local magnates donated tens of millions of yen to the Residency Procurement Movement outside of that which they had already contributed to the fund collection movement (Kang T'aek-u 1992, 191).

Designating 1970 as the "year of the completion of residency procurement," the front pages of Mindan publications featured such phrases as "Let's achieve a stable livelihood by acquiring permanent residency" and "Expo invitations are only possible through Mindan." In the meantime, more than five thousand people registered for family invitations. In addition, in order to increase the number of people allowed to travel abroad, Mindan executives organized a team for visiting the homeland, meeting with the foreign affairs minister, prime minister, and Korean Central Intelligence Agency, whereby the Korean government agreed to a twofold increase (Pak Pyŏng-hyŏn 2011, 132-33). Mindan would rarely carry out this kind of subjective action after the 1970s. As 
a means of increasing the number of South Korea-affiliated "overseas Koreans" (kyopo), the family invitation initiative was clearly rooted in the Cold War system. However, quickly rising as a challenger to Chongnyoun, Mindan displayed its negotiating prowess by capitalizing on the home government's desire for overseas support. As a result, Mindan was able to appropriate the Expo support initiative toward increasing its scale and influence.

How then should one view the linkage of the family invitation and residency procurement movements? Nagano Sinich'irō (2010, 168-69) distinguishes between "patriotism" (pride pertaining to a specific, localized area) and "nationalism" (loyalty of a national citizen inspired by the process of state formation) pertaining to the psychological motivations of overseas Koreans. The "success" of the residency procurement movement and the associated family invitation movement signified an unprecedented "happy synergy" between communalistic local patriotism, underpinning the family invitations, and hometown support and nationalism, underpinning the government budget. The sense of having "my family" and "my hometown" exemplified a grand success of the possibility of coming together as one in the expansive national community known as the "Republic of Korea." The various experiences involved in this effort-planning initiatives, donating money, constructing the Korean pavilion, inviting brothers and sisters from the homeland, and receiving recognition from Mindan and the South Korean government-offered to the participants a vivid sense of just what it meant to contribute to Mindan and the state in this "new age" known as "the 1970s." Although Nagano offers a new theory of how "patriotism" transforms into "nationalism, the discussion thus far shows that the historical significance of the Expo support initiative pertains to the manner in which local patriotism and nationalism mingled and developed into a single repertory for an effective "contribution movement." This pattern of Mindan initiative, which combined "private family love and local patriotism" with "public devotion and national patriotism" continued in its support for the Sapporo Winter Olympics (1971), New Village Sisterhood (Saemaŭl Chamae Kyŏryŏn; 1972), Okinawa International Maritime Exposition (1975), and the Seoul Olympics (1988).

\section{“Zainichi” Expo: Expo Support and a New Nationally Oriented Vision}

Through active support, ethnic Koreans in Japan created a space of possibility that cannot be completely explained in terms of South Korean government or 
Mindan intentions alone. By projecting various intentions and desires onto this Expo stage, they bravely tested their capabilities, and through "success," gained a sense of what they could accomplish. In terms of transformations related to selfimage and agency, the Expo support initiative constituted an identity-building project, the most important challenge related to the formation of their collective identity in the 1970s. As mentioned above, this effort carried out by Koreans in Osaka and Japan, businessmen, and Mindan members, due to the very diversity of its constituents, was a complex enterprise involving multiple overlapping, intersecting, and sometimes antagonistic identities. But above all else, this was the identity of those who would forever be "Zainchi" Koreans, even as they were Republic of Korea nationals.

For Mindan, the campaign for Expo support and permanent residency registration constituted its first major action following the Treaty on Basic Relations between Korea and Japan. However, Mindan did not have a solid relationship with the homeland nor an organizational vision commensurate to the permanent residency system. Even if the issue of legal status had been formally settled, Mindan was lacking in any concrete vision of what to do and how to "strive" for what the future would be like for "ethnic Koreans in Japan" who were "permanent residents." Under such conditions, the Expo support initiative was an epoch-making event in terms of the formation of Mindan's selfunderstanding.

This situation would also be significant for the identity change of the "first generation." Under ambiguous conditions in which it was unclear just what kind of existence was signified by the status of "overseas Koreans" explicitly rejecting the possibility of "return," an issue bracketed heretofore with regard to permanent residency, it was those now known as "first-generation ethnic Koreans in Japan" who formed the backbone of the Expo support initiative. Faced with the problems of educating and ensuring the employment of their children born in Japan, in the late 1960s, these Koreans clearly recognized the limitations of nostalgia and kinship, instead focusing on practical and realistic measures that might ensure a stable environment for the next generation. The so-called "parent generation," which resolved to "forego sentimental nostalgia and prepare the way for the second and third generations" (Kim Pu-hwan 1977, 822), actively devoted themselves to the Expo support movement in the 1970s, the success of which presented a "homeland orientation" besides that of simple "repatriation." In other words, while confirming the new form of relations with the homeland, characterized by assistance to Korea and place of residence, they strengthened awareness of the need to take an active role in the future as they raised their children in Japan. From this perspective, the 1970 Expo in Osaka 
was a "Zainichi Expo." Here, "Zainichi" refers to the settlement that firstgeneration ethnic Koreans in Japan had shrewdly sought since liberation, as well as the new "future" and identity they had foreseen through the Expo. Since the 1970s, "Zainichi" has gradually become a common noun indicating these Koreans within Japanese society.

Since the 1990s, attitude surveys pertaining to ethnic Koreans in Japan have usually been conducted through interviews capturing the specific aspects of Korean identity relative to the first, second, and third generations. This kind of research tends to emphasize generational difference vis-à-vis the "repatriation/ homeland orientation" of the first generation and "Japanese settlement orientation" of subsequent generations. The preceding investigation, however, shows that first-generation Koreans in Japan began to actively seek out a means of harmoniously combining "settlement" and "homeland orientation" through the Expo support initiative once the issue of residency had been resolved. If identity is something that changes as it is negotiated, pursued, and embraced through specific events, the importance of the 1970 World Expo in Osaka support initiative superseded the simple dichotomy of "homeland orientation versus settlement" for first-generation Koreans in Japan. Indeed, the importance of this event can be ascertained in the manner in which it experimented with and dramatically developed the new sense of identity among first-generation Koreans in Japan as "contributors to the homeland."

\section{Conclusion: Toward a Historical Sociology of Homeland Contributions by Ethnic Koreans in Japan}

The "contributions" of ethnic Koreans in Japan cannot be understood purely in terms of "love for the homeland" or "patriotism." The trauma of colonization and discrimination became intricately intertwined with resistance nationalism, Cold War anti-communism, nationalism, and developmentalism, which allowed Koreans in Japan to overcome these negative experiences. Thus, the large-scale donations and devoted effort that began in earnest in the 1970 World Expo in Osaka manifested itself within this struggle to succeed and transform this cultural tradition and self-understanding. The Expo support initiative was the result of social capital accumulating through local trust and cooperation. It represented the struggle to demonstrate the collective capability of a diverse group of people, to attain recognition from the homeland, and to construct a new self-identity for Korean and Japanese futures in a "new age" - the 1970s.

Incidentally, as one may ascertain in the recent demands for the recognition 
of the "homeland contributions" of these Koreans in school textbooks, the communication feedback loop of these "contributions" has yet to close, even after fifty years. This signifies a failure of reciprocity or recognition, engendering an incomplete dialogical-dialectical cycle, where "contributions" become a nondialogic dissemination breeding varied, scattered effects and rendering the flow of history all the more deep and complex. How might one more productively explore the complexity and dynamism of "contributions" in their yet incomplete form? I conclude this article by considering some limitations and future challenges with respect to this question.

First, one may illuminate the macroscopic complexity of "contributions" by considering more diverse agency and perspectives. The Expo support initiative, for example, may be approached in terms of diverse agents and constituents, including the Mindan Wives Association, general members, and rural activists, as well as in terms of gender, region, and class. Meanwhile, one can also consider the multilayered perspectives of the South Korean public, Chongnyon, and the Japanese government or Japanese people. In particular, questions remain pertaining to the commonalities and differences, as well as mutual influence between Chongnyŏn and Mindan "contributions."

Second, for a more in-depth understanding of the historicity of "contributions," there is also a need for more comprehensive analysis regarding macroscopic change rather than individual events. In other words, one cannot discount the ethos allowing for the "imagining of the future" and the calculation of interests and communal passion serving as the cultural basis for the repeated "contributions" of ethnic Koreans in Japan. This means incorporating the emphasis on economic growth characterizing the "faith in the future" that mobilized the masses in both Korea and Japan since the 1970s. Considering the historical ebb and flow of this developmentalist ideology, it may be possible to reconceive the structure of feeling of support for the homeland among ethnic Koreans in Japan devoted to Mindan over the past fifty years as the "postwar history of the contributions of ethnic Koreans in Japan."

Third, the dynamism of "contributions" in contemporary Korean history can be investigated by actively questioning the meaning of the agency of ethnic Koreans in Japan. As examined in this article, ethnic Koreans in Japan displayed ample agency, irreducible to a single layer of meaning as they appropriated the Expo for their own purposes. The characteristics of the various influential relations revealed therein were robust and irreducible to the "offerings" or "roles" of overseas Koreans. These were not characteristics languishing in the past but and novel acts discovered retroactively. They stimulate to an unprecedented degree the study of Korean history by demanding interpretation of 
their potential. Mindan's subjectivity in viewing the South Korean government as an interlocutor with respect to family invitations, for example, offers great implications and opportunities for reflection to the contemporary researcher.

Currently discussion is underway in Japan regarding the 2025 World Exposition in Osaka that will follow the 2020 Tokyo Olympic Games. In 1969, ethnic Koreans in Osaka proclaimed, "If the 1964 Olympics were for Tokyo, then now it's Osaka's turn to flourish," as they threw themselves wholeheartedly into the Expo support initiative. The current situation, however, is quite different. The "win-win model of contribution" that was established in the 1970s and tethered the South Korean government to Mindan and the Korean business community in Japan, naturally expanded to include homeland investment and support for government activities. But this reciprocal relationship degraded into one of subservience, characterized by "Yusin Mindan's" blind obedience to the home government, and today Mindan still faces criticism for failing to adjust to a changing reality and degenerating into a "subordinate institution of the government” (Kim T’ae-gi 2000). Meanwhile, not only have Korean businessmen in Japan come to largely disregard the necessity of doing business with nationally affiliated financial institutions and "devotion" to Mindan, they have also largely come to be associated with the legacy of a bygone era of governmentbusiness cooperation engendering the "cozy relations between politics and business." In this way, looking back on the "contributions" of ethnic Koreans in Japan should not consist of erecting "national heroes" or, conversely, reducing their conduct to simple calculated interest or external pressure. The task of critically questioning and deeply appreciating the complexity, historicity, and dynamism of "contributions" is one that involves confronting ambivalence vis-àvis the legacies of colonialism and state building in both Korea and Japan, as well as reinventing a new future from the past. Perhaps this is the great challenge that lies ahead.

- Translated by Keiran MACRAE

Acknowledgments | This article is a shortened and translated version of the author's Korean article, “'Zainichi’ ŭi Manbak: 1970-nyŏn Ilbon Man'guk Pangnamhoe tangsi Chae-Il Han'gugin Manbak Huwŏnhoe ŭi hwaltong," published in Sahoe wa yŏksa [Society and History] 113 (2017), with the permission of Han'guk Sahoesa Hakhoe [Korean Social History Association]. 


\section{List of References}

Kankoku shinbun [Korea News].

Korian supōtsu taimuzu [Korean Sports Times].

KPI tsūshin [KPI Communication].

Kyŏnghyang sinmun [Trend News].

Maeil kyŏngje sinmun [Daily Economy News].

Mindan shinbun [Mindan News].

Shinsekai shinbun [New World News].

Tonga ilbo [East Asia Daily].

Adler, Paul S., and Seok Woo Kwon. 2000. "Social Capital: The Good, the Bad, and the

Ugly." In Knowledge and Social Capital: Foundation and Application, edited by

Eric L. Lesser, 89-115. Boston: Burtworth-Heinemann.

Anderson, Benedict. 1994. "Exodus." Critical Inquiry 20 (2) (Winter): 314-27.

Bourdieu, Pierre. 1986. “The Forms of Capital.” In Handbook of Theory and Research for Sociology of Education, edited by J. G. Richardson, 241-58. New York: Greenwood Press.

Bourdieu, Pierre. 2015. "Chabon ŭi hyŏngt'ae" [The Forms of Capital]. In Sahoejabon iron kwa chaengjŏm [Social Capital: Theories and Issues], edited and translated by Yu Sŏk-ch'un, Chang Mi-hye, Chŏng Pyŏng-ŭn, and Pae Yŏng, 61-88. Seoul: Kŭrin.

Chae-Ilbon Taehanmin'guk Mindan [Republic of Korea Mindan in Japan]. 2016. ChaeIlbon Taehanmin'guk Mindan changdan 70-junyŏn kinyŏmsikchŏn kongsik p'amp'üllaet [Pamphlet Commemorating Seventieth Anniversary of the Founding of Mindan].

Chaeil Tongp’o Moguk Kongjŏk Chosa Wiwŏnhoe [Overseas Koreans in Japan Homeland Public Investigation Committee]. 2008. Chaeil tongp’o ŭi 100-nyŏn chokchŏk [One Hundred Year Footprint of Overseas Koreans in Japan]. Seoul: Chaeoe Tongpo Chaedan.

Dayan, Daniel, and Elihu Katz. 2011. Midiǒ ibent'ŭu [Media Event]. Translated by Kwak Hyŏn-ja. P’aju: Hanul Ak’ademi.

Derrida, Jacques. 1992. Given Time: I. Counterfeit Money. Translated by Peggy Kamuf. Chicago: University of Chicago Press.

Ha Myŏng-saeng. 2003. Mainoriti no kigyōka seishin: Zainichi Kanjin jirei kenkyū [The Entrepreneurial Spirit of Minorities: Case Study of Korean Residents in Japan]. Tokyo: Kabushikigaisha ITA.

Han Chae-hyang. 1997. Minzoku kin'yü kikan no zenkoku tenkai [Period of Nationwide Financial Expansion]. MMRC Discussion Paper No.175. Tokyo: Tokyo Daigaku COE Monozukuri Keiei Kenkyū Sentā.

Han Chae-hyang. 2010. “Zainichi kigyō” no sangyō keizai shi [Industrial and Economic 
History of “Zainichi Business”]. Nagoya: Nagoya Daigaku Shuppanbu.

Hosan Kang Kye-jung Kanhaeng Palgi Wiwŏnhoe [Hosan Kang Kye-jung Publication Committee], ed. 1979. Hosan Kang Kye-jung. Seoul: Hosan Kang Kye-jung Palgi Wiwŏnhoe.

Kang T’aek-u. 1992. Kang T’aek-u chajŏn [Memoirs of Kang T’aek-u]. Suita: individually published.

Kim Pu-hwan. 1977. Zainichi Kankokujin shakai shōshi [A Brief History of Korean Residents in Japan]. Kyōdō Shuppansha.

Kim T’ae-gi. 2000. "Han'guk chŏngbu wa Mindan ŭi hyŏmnyŏk kwa kaltŭng kwan'gye" [Cooperation and Conflict between the South Korean Government and Mindan]. Asia t’aep'yŏngyang chiyŏk yŏn'gu [Asia Pacific Studies] 3 (1): 83-84.

Krämer, Sybille. 2015. Medium, Messenger, Transmission: An Approach to Media Philosophy. Amsterdam: Amsterdam University Press.

Lin, Nan. 2001. Social Capital: A Theory of Social Structure and Action. New York: Cambridge University Press.

Mindan Kanagawa 60-nenshi Hensan Iin kai [Kanagawa Sixtieth Annual History Committee]. 2006. Mindan Kanagawa 60-nenshi [Sixty Year History of Mindan Kanagawa]. Yokohama: Zai-Nihon Daikanminkoku Mindan Kanagawa-ken Chihō Honbu.

Mindan Tokyo 50-nenshi Hensan Iinkai [Mindan Tokyo Fifty Year History Compilation Committee]. 1998. Mindan Tokyo 50-nenshi [Mindan Tokyo Fifty Year History]. Tokyo: Zai-Nihon Daikanminkoku Mindan Tokyo Chihō Honbu.

Nagano Sin'ichirō, ed. 2010. Han'guk ŭi kyŏngje palchŏn kwa Chaeil Han'guk kiŏbin

[South Korean Economic Development and Korean Businessmen Residing in Japan]. Seoul: Malgŭl Pinnaem.

Osaka Kankokujin Shōkōkai [Korean Chamber of Commerce and Industry in Osaka]. 1973. Osaka Kankokujin Shōkōkai 20-nen no yumi [Twenty Year Journey of the Korean Chamber of Commerce and Industry in Osaka]. Osaka: Osaka Kankokujin Shōkōkai.

Osaka Kankokujin Shōkōkai [Korean Chamber of Commerce and Industry in Osaka]. 1983. Osaka Kankokujin Shōkōkai 30-nenshi [Thirty Year History of the Korean Chamber of Commerce and Industry in Osaka]. Osaka: Osaka Kankokujin Shōkōkai.

Osaka Kankokujin Shōkōkai [Korean Chamber of Commerce and Industry in Osaka]. 1985. Osaka Kankokujin Shōkōkai 30-nenshi [Thirty Year History of the Korean Chamber of Commerce and Industry in Osaka]. Osaka: Osaka Kankokujin Shōkōkai.

Osaka Kankokujin Shōkōkai [Korean Chamber of Commerce and Industry in Osaka]. 1988. Shashin de miru 35-nenshi [Thirty-Five Year History through Photographs]. Osaka: Osaka Kankokujin Shōkōkai [Korean Chamber of Commerce and Industry 
in Osaka].

Osaka Kōgin [Osaka Industrial Bank of Japan]. 1987. Osaka Kōgin 30-nenshi [Thirty Year History of the Osaka Industrial Bank of Japan]. Osaka: Osaka Kōgin [Osaka Industrial Bank of Japan].

Pak Pyŏng-hŏn. 2011. Watashi no ayunda michi [My Journey]. Tokyo: Shinkansha.

Peters, John D. 1999. Speaking Into the Air: A History of the Idea of Communication. Chicago: The University of Chicago Press.

Putnam, Robert. 1993. “The Prosperous Community: Social Capital and Public Life." The American Prospect 13 (Spring): 35-42.

Putnam, Robert. 2015. "Pŏnyŏng hanŭn kongdongch'e: sahoejabon kwa konggongsaenghwal” [The Prosperous Community: Social Capital and Public Life]. In Sahoejabon iron kwa chaengjŏm [Social Capital: Theories and Issues], edited and translated by Yu Sŏk-ch'un, Chang Mi-hye, Chŏng Pyŏng-ŭn, and Pae Yŏng, 125-40. Seoul: Kŭrin.

Shipper, Apichai W. 2008. Fighting for Foreigners: Immigration and Its Impact on Japanese Democracy. Ithaca and London: Cornell University Press.

Shipper, Apichai W. 2010. "Nationalisms of and against Zainichi Koreans in Japan." Asian Politics \& Policy 2 (1) (January/March): 55-75.

Uphoff, Norman. 2000. "Understanding Social Capital: Learning from the Analysis and Experience of Participation." In Social Capital: A Multifaceted Perspective, edited by Partha Dasgupta and Ismail Serageldin. Washington, D.C.: World Bank.

Yang Kyŏng-hŭi. 2009. “Zainichi Kankokujin kigyōka ga Kankoku no kin’yū gyōkai ni oyoboshita eikyō: Shinkan Ginkō o chūshin ni” [The Influence of Korean Resident Businessmen on the Financial Industry in Korea: Focusing on Shinhan Bank]. Gendai Kankoku Chōsen kenkyū [Modern Korean Studies] 9: 16-30.

Yi Hyŏn-jin. 2010. “Pak Chŏnghŭi chŏngbu chogi tae-Il kyŏngje hyŏmnyŏk chŏngchaek ŭi ch'ujin kwajŏng” [The Policy Process regarding Economic Cooperation with Japan in the Early Years of the Park Chung-hee Administration]. In Han'guk kŭnhyŏndae chŏngch'i wa Ilbon [Contemporary South Korean Politics and Japan]. Seoul: Sŏnin.

Yi Min-ho. 2014. Mindan ŭn Taehanmin'guk kwa hana ida [Mindan is One with the Republic of Korea]. Tokyo: Chae-Ilbon Taehanminguk Mindan Chungang Ponbu [Mindan Central Headquarters].

Yi Min-ho. 2015. Chainich'i ridŏ [Zainichi Leader]. Seoul: T’ongil Ilbo.

Yoshimi Shun'ya. 2004. Pangnamhoe [The Politics of Exposition]. Translated by Yi T’ae-mun. Seoul: Nonhyŏng.

Yi Min-ho. 2011. Banpaku to sengo Nihon [The Expo and Postwar Japan]. Tokyo: Kōdansha.

Zainichi Kankokujin Banpaku Kōenkai [Korean Residents in the Japan World Expo Association] and Zainichi Daikanminkoku Kyoryūmindan [Republic of Korea 
Koreans in Japan Residents Group]. 1970. Chaeil han'gugin manbak huwŏnhoe kinyŏm suchŏp [Korean Residents Association for the Support of EXPO '70 Expo Commemorative Notebook]. Osaka.

Zai-Nihon Daikanminkoku Mindan Aichi-ken Chihō Honbu [Republic of Korea Mindan Aichi Prefecture Regional Headquarters]. 2007. Mindan Aichi-ken Honbu 60-nen no ayumi [Sixty Year History of Mindan Aichi Regional Headquarters] 145. 
